\title{
Elite Sport Ranking of the "International Society of Sports Sciences in the Arab World": An Accurate Evaluation of all Nations' Performances in International Sports Competitions
}

\begin{abstract}
By Nadim Nassif $f^{*}$
The International Society of Sports Sciences in the Arab World (ISSAW) has published (AIPS 2015) an annual elite sport ranking for 2014 by collecting the results across 204 National Olympic Committees (NOCs) for 35 sports, which are part of the Summer and Winter Olympic programs. This ranking of countries was based on a new methodology that computes points for the results obtained by countries in each sport. These points were then multiplied by welldefined coefficients attributed to each sport based on its level of universality and popularity, with the country's final score resulting from the addition of points in each of the 35 Olympic sports. Unlike the Olympic medal table, the I3SAW System allows the ranking of each country having a National Olympic Committee. This system also rewards countries that have achieved consistent results, and presented a larger number of athletes who have succeed in several disciplines, in addition to the sports involving a higher level of competition. The main objective of this paper is to present this new methodology and model, which led to a new international sport ranking in 2014. The study also covers the year 2015 by adding 17 non-Olympic sports chosen for their sum-value of universality and popularity coefficients, which are equal or equivalent to one of the Olympic sport. This annual ranking would, therefore, reward countries that are most efficient in establishing elite sport policies. As such, this paper aims at providing a measure for the countries' performance, which the various national sport authorities, media, and scholars could better utilize in the field of sports sciences.
\end{abstract}

Keywords: Elite sport, Metals, Olympic Games, Ranking, Sport competition

\section{Introduction}

According to the Olympic Charter, the International Olympic Committee (IOC) and the local organizing committees of the Olympic Games shall not draw up any global ranking per country (IOC 2014). Scholars in the field of sport sciences, however, refer to the Olympic Medal Table when they want to measure the performance of a country in international competitions (Adami 2004, Andersen \& Ronglan 2015, Bravo \& Silva 2014, De Bosscher et al. 2008a, Nassif \& Amara 2015, Sam \& Jackson 2015). Media and politicians also use this table to compare success in elite sport (De Bosscher et al. 2006).

In fact, the global acknowledgment of the medal table arises from the fact that the Olympic Games are the most universal, multidisciplinary competition in the world. Evidence to that is the participation of the 204 National Olympic Committees in the London 2012 Olympic Games. Due to the universality and media coverage of this event (IOC 2012), most governments have decided to invest substantial funds in the sports, which are part of the Olympic program.

\footnotetext{
${ }^{*}$ Assistant Professor, Notre Dame University - Louaize (NDU), Lebanon.
} 
In this paper, we start by discussing the non-correctness of the Olympic medal classification, and then propose a new model, whose main features are:

a) A weighted points system that replaces the three-medal Olympic system in any event, discipline, or sport (see the glossary in Table 1).

b) The introduction of universality and popularity coefficients for each sport being considered.

c) A computation model that attributes to each country its' share of points in at least one sport, and, consequently, its ranking in the "global sporting arm race" (De Bosscher et al. 2008b) on the basis of the total number of points, which this country would have garnered in all sports.

Table 1. Glossary

\begin{tabular}{|l|l|l|}
\hline Term & Definition & Examples \\
\hline Sport & $\begin{array}{l}\text { A group of disciplines or events } \\
\text { that belong to the same } \\
\text { international federation }\end{array}$ & Aquatics \\
\hline Discipline & $\begin{array}{l}\text { A branch in a sport comprising one } \\
\text { or more events }\end{array}$ & $\begin{array}{l}\text { Swimming is a discipline in the } \\
\text { sport of aquatics }\end{array}$ \\
\hline Event & $\begin{array}{l}\text { A competition in a sport or } \\
\text { discipline that gives rise to a } \\
\text { ranking }\end{array}$ & $\begin{array}{l}\text { Men 50-M freestyle is an event of } \\
\text { the discipline of swimming that } \\
\text { belongs to the sport of aquatics }\end{array}$ \\
\hline
\end{tabular}

Source: IOC (2015a).

The model has been applied to the year 2014, and is currently carried out for 2015 , in view of its implementation on a yearly basis.

\section{Lack of Accuracy of the Olympic Medal Table}

The Olympic Medal Table is a ranking model that computes the gold, silver, and bronze medals obtained by the different countries in the different sport events, in every edition of the Summer and Winter Olympic Games. A gold medal has superior value over any number of silver. A silver medal has superior value over any number of bronze. In the event where two countries obtain the same number of gold, the country with more silver medals is better ranked. In the case where two countries obtain the same number of gold and silver medals, the country with more bronze medals will be better ranked.

Despite its popularity, the Olympic medal ranking has some limitations, which prevent it from being a precise measurement tool for countries performances in international sport.

First, the superiority of a gold medal over any number of silver, and of a silver medal over any number of bronze will create situations, where a country having only one exceptional athlete capable of winning a gold medal is placed in front of another one endowed with several athletes who were placed second and third. This methodology creates the false inference, whereby a country with only one gold medal has a better elite sport policy than another country with five silver medals and seven bronze but no gold. 
Second, the number of medals awarded per event don't take into account neither the level of competition of the sport involved, nor the number of countries and athletes involved. For example, a sport like sailing comprises of several events (i.e. Women's RS:X, Laser Radial, Women's 470, Eliott 6m, Men's RS:X, Laser, Finn, Men's 470 and 49er), is played in 115 countries, and awards 10 gold medals. Whereas a sport like basketball has only two events (Men and Women Basketball), is played in 215 countries, and awards only two gold medals. Moreover, as an individual sport, sailing awards medals to several athletes of a same country; whereas basketball, as a team sport, only awards one medal per country. In that sense, following the Olympic Medal Table methodology, a minor sport could outweigh a major sport, which is more popular, universal, and competitive. This measurement is, therefore, misleading in the comparison of elite national sport policies.

\section{The 2014 I3SAW Elite Sport Ranking Methodology}

In order to suggest a more comprehensive country classification, which takes into account the issues presented above, Nassif (2015) has developed an elite sport ranking methodology that was presented at the first Conference of the International Society for Sports Sciences in the Arab World (I3SAW). This society comprises scientists and specialists in sport practice, who aim at developing sports sciences in the Arab World.

The objective of this endeavor was to propose a methodology that rewards countries with consistent results and presents a larger number of successful athletes, who win in the most competitive events. This methodology relies on the calculation of two coefficients that weigh the different sports: popularity and universality.

Popularity indicates the international media ratings for each sport. It shows to which extent a sport is covered; consequently, how much this sport attracts private and public funding and raises competition level by engaging the most talented athletes.

Universality takes into account the number of all countries participating in a given sport. The more countries participating, the more difficult it is for them to win in an event.

Such parameters are obviously not being considered in the Olympic Medal Table. By taking into account the universality and popularity of each sport, our goal is to give a differential weight for minor sports like curling or luge, and major sports like football and basketball. Our proposed model will be therefore as follows:

- Attributing distinct coefficients for the universality and popularity of each sport; and

- Computing a scaled score for each nation. 
Specifically, in our model, the ranking will start with each country obtaining a score computed on the basis of its position in every event ranking. Such ranking takes into consideration:

- Only the events that were part of the Summer and Winter Olympics Games. Being part of the Olympic program is a guarantee of this sport universality; therefore, a very efficient tool to compare elite sport policies among different nations.

- Only the countries that have National Olympic Committees were ranked because they have access to the highest number of sports.

- The number of National Olympic Committees that participated in the 2012 Olympics (last Summer Olympics to date) is 204. Thus, any team (basketball, handball...) or individual (athletics, swimming, wrestling...) competitor obtains a basic score of 204; the second achieves 203; the third 202 , etc.

To reward the top eight countries, we introduce a weighting coefficient inspired from the Formula 1 scores, which were adopted between 2003 and 2009 (Formula 1 2003). This weight is well indicated in the third column of Table 2. We believe that multiplying NP basic by 10 (gold medal) for the first ranked, by eight for the second (silver medal), and by six for the third (bronze medal) would deny a country having athletes reaching the ninth and tenth positions (scoring 391 points) come ahead of the champion's country that receives now a score of 2040.

All those ranked eighth and above will obtain points that decrease from 197 to 1. If, for example, there are only 200 countries participating, the last of which will obtain five points. If there are 190, the last will obtain 10 points. The points earned in each event were added to determine the ranking of countries in each event. With these criteria, the objective was to avoid situations of having countries with 1 gold medal, 0 silver and 0 bronze, ranked in front of some that won 0 gold medal, 5 silver medals and 7 bronze medals. This is a major difference with the Olympic ranking that only uses medals for the top three competitors in each event.

On that basis, given an event E, we obtain a total number of points per event for each country by summing up the points received by its athletes in that event. A ranking would result with a number of points attributed for each country in that event according to the scale of Table 2. Table 3 provides an example illustrating points, ranking, and scaled final number of points in an event E such as $100 \mathrm{M}, 200 \mathrm{M}$, etc.

The sum of points of rankings of a given country in each event is then totaled by sport for each of the 35 Olympic sports. For example, the sum of the points within the events of $100 \mathrm{M}, 200 \mathrm{M}$, shot put, marathon, etc. are computed to determine the countries ranking in athletics. This method was applied to avoid having a sport that has a multitude of events (athletics, boxing) award more points than a team sport that has just two events (example of basketball: men/women). Table 4 provides a sample of sports in which this summing-up rule is being applied. 
Table 2. Points Classification within an Event, Discipline or Sport

\begin{tabular}{|l|c|c|c|}
\hline $\begin{array}{l}\text { Rank in an } \\
\text { event, } \\
\text { discipline } \\
\text { or sport }\end{array}$ & $\begin{array}{c}\text { Basic Number Points } \\
\text { awarded on the basis of } \\
\text { number of Olympic } \\
\text { committees: NP_basic }\end{array}$ & $\begin{array}{c}\text { Weight } \\
\text { (Formula 1 } \\
\mathbf{2 0 0 3 - 2 0 0 9} \\
\text { scale) }\end{array}$ & $\begin{array}{c}\text { Weighted basic } \\
\text { number of } \\
\text { points: } \\
\text { NP_weighted }\end{array}$ \\
\hline 1 & 204 & 10 & 2040 \\
\hline 2 & 203 & 8 & 1624 \\
\hline 3 & 202 & 6 & 1212 \\
\hline 4 & 201 & 5 & 1005 \\
\hline 5 & 200 & 4 & 800 \\
\hline 6 & 199 & 3 & 597 \\
\hline 7 & 198 & 2 & 396 \\
\hline 8 & 197 & 1 & 197 \\
\hline 9 & 196 & 1 & 196 \\
\hline 10 & 195 & 1 & 195 \\
\hline 11 & 194 & 1 & $\ldots \ldots$ \\
\hline$\ldots \ldots$ & $\ldots \ldots$ & $\ldots \ldots$ & 182 \\
\hline 23 & 182 & $\ldots \ldots$ & $\ldots \ldots$ \\
\hline$\ldots \ldots$ & $\ldots \ldots$ & & \\
\hline
\end{tabular}

Source: Author's Calculations.

Table 3. Example of Ranking and Scaled Points Granting for a Country in an Event E

\begin{tabular}{|l|c|c|c|}
\hline Ranking of athletes in event E & Points & $\begin{array}{c}\text { Corresponding Ranking of } \\
\text { countries in event E }\end{array}$ & Points \\
\hline 1 USA & 2040 & 1. Brazil 2836 (1624+1212) & 2040 \\
\hline 2 Brazil & 1624 & 2. USA (2040) & 1624 \\
\hline 3 Brazil & 1212 & 3. France 1202 (1005+197) & 1212 \\
\hline 4 France & 1005 & 4. Italy (993) & 1005 \\
\hline 5 Spain & 800 & 5. Spain (800) & 800 \\
\hline 6 Italy & 597 & & \\
\hline 7 Italy & 396 & & \\
\hline 8 France & 197 & & \\
\hline Sourc:
\end{tabular}

Source: Author's Calculations.

Table 4. Sample of Sports in which the "Summing-up Rule" is being Applied

\begin{tabular}{|l|l|}
\hline $\begin{array}{l}\text { Sports } \\
\text { Examples }\end{array}$ & \multicolumn{1}{c|}{ Points } \\
\hline Athletics & $\begin{array}{l}\text { Sum of the points gained in the different men's and women's athletics } \\
\text { events (pole vault, long jump, high jump, triple jump, 100M, Marathon...) } \\
\text { countries rankings }\end{array}$ \\
\hline Basketball & $\begin{array}{l}\text { Sum of the points gained in the men's and women's basketball events } \\
\text { countries rankings }\end{array}$ \\
\hline Cycling & $\begin{array}{l}\text { Sum of the points gained in the different men's and women's road, track, } \\
\text { mountain bike, and BMX events countries rankings }\end{array}$ \\
\hline
\end{tabular}

Source: Author's Calculations. 
The ranking in each sport followed the same pointing system, which was used for the event ranking: 2,040 for the first, 1,624 for the second, 1,212 for the third, 1,005 for the fourth and so on.

\section{Universality Coefficient}

As an indicator of universality, Nassif (2015) used the number of countries affiliated to the international federation of each sport. This number was then divided by 100 in order to have a number between 0 and 5 .

\section{Popularity Coefficient}

As for the popularity, Nassif (2015) considered the financial gains that each sport generated in the 2012 Olympics.

Table 5. Popularity Coefficient

\begin{tabular}{|l|c|c|}
\hline Groups & Sports & $\begin{array}{c}\text { Popularity } \\
\text { Coefficients }\end{array}$ \\
\hline A & Aquatics, Athletics, Gymnastics & 5 \\
\hline B & Basketball, Cycling, Football, Tennis Volleyball & 4 \\
\hline C & $\begin{array}{c}\text { Archery, Badminton, Boxing, Judo, Rowing, Shooting, } \\
\text { Table Tennis, Weightlifting }\end{array}$ & 3 \\
\hline D & $\begin{array}{c}\text { Canoe/Kayak, Equestrian, Fencing, Handball, Hockey, } \\
\text { Sailing, Taekwondo, Triathlon, Wrestling }\end{array}$ & 2 \\
\hline E & Modern Pentathlon, Golf, Rugby & 1 \\
\hline
\end{tabular}

Source: Author's Calculations.

For the winter sports, coefficients were set based on Winter Olympics media ratings (the active times, 2014) and their comparison with Summer Olympics media ratings (Table 5).

In this early model, the points obtained from the ranking in each sport were then multiplied by a coefficient that is the product of popularity and universality indicators. As for the competitions chosen, Nassif (2015) considered that the international federations are the best place to learn what the major competitions of their sport. He, therefore, used the official ranking made by these federations. When there was no ranking available depending on the year, the results of the last world championships or the Olympics to date were used. All the results must have been taken before January $1^{\text {st }}, 2015$. Examples of the calculation are shown in Table 6. 
Table 6. Example of the Final Computation Rule for the 2014 Ranking

\begin{tabular}{|l|c|c|c|c|}
\hline Sports & Competitions chosen & Universality & Popularity & $\begin{array}{c}\text { Total = } \\
\text { Universality x } \\
\text { Popularity }\end{array}$ \\
\hline Basketball & $\begin{array}{c}\text { Last 2014 International } \\
\text { Basketball Federation } \\
\text { rankings to date }\end{array}$ & 2.04 & 4 & 8.16 \\
\hline Cycling & $\begin{array}{c}\text { Last 2014 International } \\
\text { Cycling Union rankings to } \\
\text { date }\end{array}$ & 1.57 & 4 & 6.28 \\
\hline
\end{tabular}

Source: Author's Calculations.

The points won by each country in each of the 35 sports after the coefficient multiplications were added in order to obtain the total amount of points. An example is illustrated in Table 7.

Table 7. Total Number Points Computed for Each Country before the Final Ranking

\begin{tabular}{|l|c|c|c|}
\hline & USA & RUSSIA & GERMANY \\
\hline Aquatics & 20808 & 10251 & 1989 \\
\hline Biathlon & 44 & 281 & 46 \\
\hline Basketball & 16646 & 13252 & 1436 \\
\hline Boxing & 11995 & 2328 & 4794 \\
\hline$\ldots$ & $\ldots$ & $\ldots$ & $\ldots$ \\
\hline TOTAL & $\mathbf{1 7 4 7 2 9}$ & $\mathbf{1 3 0 7 6 4}$ & $\mathbf{1 2 0 3 3 7}$ \\
\hline
\end{tabular}

Source: Author's Calculations.

The final ranking was done according to the "summed" total amount of points. This methodology allowed the 204 countries that participated in the 2012 Olympics to be included and, therefore, made it possible to all national sport authorities to have an idea of their ranking in international sport competitions. It also offered different results from the Olympic Medal Table, rewarding some countries (i.e. Spain, Argentina and Brazil), which succeeded in highly universal and popular sports (i.e. football, basketball and volleyball) and scaling appropriately those who mainly won several medals in minor sports (i.e. Norway and Switzerland win most of their medals in winter sports, where, in comparison to summer sports, a much smaller number of countries participate).

In Table 8, we can see in bold the countries ranked in the top 20 in the I3SAW elite sport ranking and unranked in the top 20 of the Olympic Medal Table. In italics, the countries ranked in the top 20 of the Olympic Medal Table and unranked in the top 20 of the I3SAW elite sport ranking.

The first ranking resulting from this methodology was compiled for the year 2014, and published by the Lebanese Sports Redactors Association in the International Sports Press Association (AIPS 2015). 
Table 8. Comparisons between the Top 20 in the 2012-2014 Olympic Medal Table and the 2014 I3SAW Elite Sport Ranking

\begin{tabular}{|l|c|c|}
\hline Rank & 2012-2014 Olympic Medal Table & 2014 I3SAW Elite sport ranking \\
\hline 1 & USA & USA \\
\hline 2 & China & Russia \\
\hline 3 & Russia & Crmany \\
\hline 4 & Great Britain & France \\
\hline 5 & Germany & Japan \\
\hline 6 & South Korea & Great Britain \\
\hline 7 & France & Australia \\
\hline 8 & Netherlands & South Korea \\
\hline 9 & Norway & Italy \\
\hline 10 & Canada & Spain \\
\hline 11 & Japan & Brazil \\
\hline 12 & Italy & Mexico \\
\hline 13 & Switzerland & Netherlands \\
\hline 14 & Hungary & Canada \\
\hline 15 & Australia & New Zealand \\
\hline 16 & Ukraine & Poland \\
\hline 17 & Belarus & Hungary \\
\hline 18 & Kazakhstan & Ukraine \\
\hline 19 & Czech Republic & \\
\hline 20 & Poland & \\
\hline Sourc: Ausa & & \\
\hline
\end{tabular}

Source: Author's Calculations.

\section{The 2015 Methodology}

For the 2015 ranking, Nassif (2015) adopted a different methodology. In fact, he went beyond the 2014 edition that only included the sports which were part of the Olympic program due to their universality and popularity. Nassif (2015) reexamined this fact considering that some non-Olympic sports are likely to be more universal and popular than those that are part of the Olympic program.

For this purpose, he undertook a deeper analysis of the development of a much wider range of sports that include all those members of "Sportaccord", an organization sanctioned by the IOC. Nassif (2015) evaluated also some sports that were not recognized by "Sportaccord" (i.e. Australian rules, football, rugby league, and mixed martial arts). These sports were observed because of their significant media popularity rate, which was calculated by the Economics graduate Michael Brown. In 2014, Brown created a database of all global sports following a thorough tracking of sports news websites for 16 countries that accounted for more than $60 \%$ of the world's population size and economic wealth (United States of America, Germany, China, France, India, Russia, Japan, Brazil, United Kingdom, Italy, Mexico, Australia, Turkey, Canada, South Korea and Spain). Brown's model will be reassessed for the same countries in 2015, in addition to new ones (tracking of sport websites in Nigeria, South Africa, Saudi Arabia and the Netherlands. For the year 2016, he will extend his pool of countries to include the sports rating in Pakistan, Poland, Argentina, Kenya and Thailand). 
Brown's research has, therefore, allowed the I3SAW ranking to have a much more detailed popularity rating than the ranking provided in Nassif's (2015) 2014 model. Information on every discipline (such as swimming, diving, synchronized swimming, water polo) obtained through a precise pointing system, has been given instead of an approximate data on a sport as a whole (that is Aquatics). Indeed, in a sport like aquatics, media popularity will strongly differ between the disciplines of swimming and synchronized swimming. Brown's new perception infringes also on popularity ratings of gender divisions in each sport. The popularity coefficient was obtained by calculating the number of points given by the website "biggestglobalsports" (Brown 2014), edited by Michael Brown. This number is again divided by 100 . This was done to scale avoiding, therefore, a very high number of points for the total coefficient.

As for the universality rating, Nassif (2015) goes beyond his previous model, adopting a much deeper methodology. Instead of doing a calculation based only on the number of affiliated national federations, he takes into consideration whether a sport is part of the programs of the Olympics; the International School Sport Federation (ISF); the International University Sport Federation (FISU); the International Military Sports Council (CISM); the International Police Sports Union (USIP); and the International Masters Games Associations (IMGA). In other terms, he takes into account all multisport organizations recognized by the International Olympic Committee (IOC 2015b). The more a sport is present in these various programs, the higher its universality coefficient will be.

Table 9 provides a summary of the calculations of each of these universality coefficients taken in this new model, the sum of which provides the total universality coefficient.

Table 9. Example of Attribution for Universality Coefficients in the 2015 I3SAW Model

\begin{tabular}{|l|c|c|}
\hline & Badminton & Judo \\
\hline Nf\%=Number of federations/100 & 1.76 & 2 \\
\hline Olympics program coeff.=2*Nf\% & 3.52 & 4 \\
\hline $\begin{array}{l}\text { ISF program coeff.=min(72, Number of national sport school } \\
\text { federations)/100 (72 being the max number of National schools } \\
\text { sports federations). }\end{array}$ & 0.72 & 0.72 \\
\hline $\begin{array}{l}\text { FISU program coeff. compulsory= min(167, Number of national } \\
\text { University sport federations)/100 (167 being the max number of } \\
\text { National University sports federations). For optional FISU, above } \\
\text { number is divided by } 2 .\end{array}$ & 0.835 & 1.67 \\
\hline $\begin{array}{l}\text { CISM program coeff.= min(134, Number of national Military } \\
\text { sport federations)/100 (134 being the max number of National } \\
\text { Military Sports Federations). }\end{array}$ & 0 & 1.34 \\
\hline $\begin{array}{l}\text { USIP program coeff.= min(66, Number of national police sport } \\
\text { federations)/100 (66 being the max number of National Police } \\
\text { sports federations). }\end{array}$ & 0 & 0 \\
\hline $\begin{array}{l}\text { IMGA program coeff.= min(100, Number of national Master sport } \\
\text { federations)/100 (100 being the max number of National Master } \\
\text { sports federations) }\end{array}$ & 1 & 0 \\
\hline Total Universality & 7.835 & 9.73 \\
\hline
\end{tabular}

Source: Author's Calculations. 


\section{Remarks}

1. When a sport is part of the Olympic program, the total number of federations' rating will be multiplied by 2 . Nassif (2015) adopted this rule for two reasons. The first is due to the fact that there are two calendars used for international competitions in an Olympic sport: one of world championships and the other for Olympic Games. These will, consequently, double the efforts of the national federations. The second reason is that an Olympic sport involves a competition between all the National Olympic Committees.

2. If a sport recognized by the ISF has less than 72 affiliated countries, the points of this sport will be the number of these countries divided by 100.

3. If a sport that is part of the FISU Compulsory Program has less than 167 affiliated countries, the points of this sport will be the number of these countries divided by 100. If it is an optional sport, this number will be divided by two.

4. If a sport recognized by the CISM has less than 134 affiliated countries, the points of this sport will be the number of these countries divided by 100 .

5. If a sport recognized by the USIP has less than 66 affiliated countries, the points of this sport will be the number of these countries divided by 100.

6. If a sport recognized by the IMGA has less than 100 affiliated countries, the points of this sport will be the number of these countries divided by 100.

The total (multiplying) coefficient for each sport will then be the sum of the popularity and universality coefficients as shown in Table 10. This addition rule breaks the previous multiplication rule used in the 2014 model, given that at this stage, there is no indication that universality and popularity are correlated.

Table 10. Total Ranking of the Universality and Popularity Coefficients in the 2015 I3SAW

\begin{tabular}{|l|c|c|}
\hline & Badminton & Judo \\
\hline Media popularity (Michael Brown Model points/100) & 2.15 & 0.277 \\
\hline Universality Coefficients (see Table 9) & 7.835 & 9.73 \\
\hline Total & $\mathbf{9 . 9 8 5}$ & $\mathbf{1 0 . 0 0 7}$ \\
\hline
\end{tabular}

Source: Author's Calculations.

This methodology has been used to calculate the universality and popularity coefficients of 112 sports. The hypothesis made by Nassif (2015) that some nonOlympic sports are more popular and universal than some Olympic sports was validated. Indeed, there are 17 non-Olympic sports (Baseball/softball, cricket, automobile, American football, squash, billiards, karate, life saving, mixed martial arts, orienteering, chess, wushu, muaythai, bodybuilding, bridge, air sports and motor racing) that have superior coefficients than luge, which is the Olympic sport that has the lowest coefficient. 
For the 2015 ranking, Nassif (2015) took into account all the sports that have coefficients at least equal or superior to the "smallest" Olympic sport. With this new methodology, 52 sports, instead of 35 (as in 2014), "made the cut".

As a result, the 2015 ranking will test countries performances in a much larger number of sports. All the results were taken for the period spanning January $1^{\text {st }}$, 2015 to December $31^{\text {st }}, 2015$. Nassif (2015) considers that, likewise 2014, the international federations are the best placed to determine the major competitions in their sport. When these federations do not submit an updated official ranking, the results of the last world championships, Olympics, or major competitions in their sport will be taken in consideration.

Indeed, for the 2014 methodology, only the Olympic disciplines of the sports that were part of the Olympic program were considered. In 2015, all the disciplines were taken into account as long as their total universality and popularity coefficient is equal or superior to 1.59 (which is the coefficient of luge). In certain disciplines, there was also a difference in popularity between gender categories. An example is illustrated in Table 11.

Table 11. Example of Detailed Coefficients for Sports and Disciplines with Gender Differentiations

\begin{tabular}{|l|c|c|c|c|c|}
\hline Sport & $\begin{array}{c}\text { Sport } \\
\text { coeff. }\end{array}$ & Discipline & $\begin{array}{c}\text { Discipline } \\
\text { coeff. }\end{array}$ & $\begin{array}{c}\text { Men } \\
\text { coeff. }\end{array}$ & $\begin{array}{c}\text { Women } \\
\text { coeff. }\end{array}$ \\
\hline Basketball & 21.8 & $\begin{array}{c}3 \mathrm{vs} 3 \\
\text { Basketball }\end{array}$ & 3.6 & 1.8 & 1.8 \\
\hline
\end{tabular}

Source: Author's Calculations.

The 2015 methodology included 127 disciplines, 71 more than in 2014. It will also be based on points; but unlike in 2014, where the sum of the points of the events were computed by sports, in 2015 , the sum of the points of the events were computed by disciplines (in case the sport in question has disciplines) and the sum of the points of the disciplines were computed by sports.

\section{Conclusion}

By proposing a detailed ranking methodology, Nassif (2015) wanted to create an accurate measurement of every country's performance in elite sport, this I3SAW ranking becoming in the future an acknowledged and used scale by media, national governing bodies and scholars.

Alternately, this research has indirectly ranked the development of 112 sports; thus, offering an indicator for the international federations on the popularity and universality of their disciplines. Since the sports' popularity and universality are likely to change every year, the pointing system of the I3SAW elite sport ranking methodology is not a static one and will, therefore, evolve annually.

The endeavor undertaken by Nassif (2015) is the first step of a larger project, which aims at identifying the factors behind the success of countries in 
international competitions. Ultimately, this is the key learning objective of the subacademic field of elite sport policy.

\section{References}

Adami S (2004) Les femmes aux jeux méditerranéens (Women in Mediterranean Games). Confluences Méditerrannée (50): 53-68.

AIPS - Lebanese Sports Redactors Association (2015) USA, Russia and Germany ranked top three countries in Elite Sport ranking. Retrieved from goo.gl/02rq6i.

Andersen S, Ronglan L (2015) Historicalpaths and policy change: institutional entrepreneurship in Nordicelite sport systems. International Journal of Sport Policy and Politics 7(2): 197-216.

Bravo G, Silva J (2014) Sport policy in Chile. International Journal of Sport Policy and Politics 6(1): 129-142.

Brown M (2014) Biggest Global Sports: A Statistics-based analysis of the world's most popular sports. Retrieved from http://biggestglobalsports.com/.

De Bosscher V, De Knop P, Van Bottenburg M, Shibli S (2006) A conceptual framework for analysing sports policy factors leading to international sporting success. European Sport Management Quarterly 6(2): 185-215.

De Bosscher V, Heyndels B, De Knop P, Van Bottenburg M, Shibli S (2008a). The paradox of measuring success of nations in elite sport. Belgeo 2: 217-234.

De Bosscher V, Bingham, J, De Knop P, Van Bottenburg M, Shibli S (2008b) The Global Sporting Arms Race: An International Comparative Study on Sports Policy Factors Leading to International Sporting Success. SPLISS. Aachen: Meyer \& Meyer.

Formula 1 (2003) Results archives website. Retrieved from goo.gl/ZNyyJW.

IOC - International Olympic Committee (2012) Factsheet: London 2012 facts and figures. Retrieved from goo.gl/MF3LLi.

IOC - International Olympic Committee (2014). Olympic Charter. Art. 57. Retrieved from goo.gl/tCZojP, p.101.

IOC - International Olympic Committee (2015a) FAQ. Retrieved from goo.gl/DVKC8e.

IOC - International Olympic Committee (2015b). Organizations recognized by the International Olympic Committee. Retrieved from goo.gl/GexBEY.

Nassif N, Amara M (2015) Sport policy and politics in Lebanon. International Journal of Sport Policy and Politics 7(2): 1-15.

Nassif N (2015) Towards a new ranking methodology for countries in international sport. Proceedings of the 1st International Congress of the International Society of Sport Sciences in the Arab World (I3SAW), "Sport in the Arab World in the 21st century: Global Perspectives and Local Challenges", 2-5 March 2015, OranAlgeria: I3SAW editions, pp.19-20.

Sam M, Jackson S (2015) Sport and small states: the myths, limits and contradictions of the legend of David and Goliath. International Journal of Sport Policy and Politics 7(3): 1-9. 